\title{
MODEL PENGAJARAN DAN PELATIHAN STRATEGI KOGNITIF (MODEL P2SK) YANG MENGEMBANGKAN KEMAMPUAN BERPIKIR KRITIS DAN KREATIF
}

\author{
Buhaerah $^{1}$, Sriyanti Mustafa ${ }^{2}$, Nur Ida ${ }^{3}$ \\ ${ }^{1}$ STAIN Parepare \\ buhaerahump@gmail.com \\ ${ }^{2,3}$ Universitas Muhammadiyah Parepare
}

\begin{abstract}
ABSTRAK
Model pengajaran dan pelatihan strategi kognitif ini menjadi salah satu acuan atau contoh untuk mendesain pembelajaran. Secara praktis, model ini menjadi petunjuk dalam meintegrasikan aspek-aspek berpikir kritis dan kreatif dengan materi pelajaran. Sehingga tujuan pembelajaran untuk mengembangkan keterampilan berpikir kritis dan kreatif dapat tercapai sekaligus penguasaan materi pelajaran. Upaya menintegrasikan materi pelajaran dengan aspek-aspek berpikir kritis dan kreatif dalam pembelajaran, diperlukan upaya-upaya yang sistematis, terukur, dan berkelanjutan. Atas dasar inilah model pembelajaran ini dikembangkan. Model pengajaran dan pelatihan strategi kognitif disingkat model P2SK yang mengembangkan kemampuan berpikir kritis terdiri dari beberapa komponen, yaitu: sintaks, sistem sosial, prinsip-prinsip reaksi, sistem pendukung, dan dampak instruksional dan pengiring.
\end{abstract}

Kata Kunci : Strategi kognitif, Berpikir kritis, Berpikir kreatif.

\section{PENDAHULUAN}

Berkenaan dengan pengertian model pembelajaran, Bell (1981) menyatakan bahwa: "A teaching/learning model is a generalized instructional process wich may be used for many different in a variety of subjects". Berdasarkan kutipan tersebut bahwa suatu model pembelajaran dapat diterapkan pada berbagai disiplin/mata pelajaran. Hal ini tidak berarti bahwa suatu model pembelajaran cocok untuk setiap topik dalam suatu mata pelajaran.

Joyce \& Weil (1999) mengemukakan bahwa: "A model of teaching is a plan or pattern that we can use to design face-to-face teaching in class rooms or tutorial setting and to shape instructional materials-including books, films, tapes, computer-mediated programs, and curricula (long term courses of study). Each model guides us as we design instructional to help students achieve various objectives”.

Menurut pernyataan tesebut menunjukkan bahwa model pembelajaran merupakan petunjuk bagi guru dalam merencanakan pembelajaran di kelas, mulai dari mempersiapkan perangkat pembelajaran, media dan alat bantu, sampai alat evaluasi yang mengarah pada 
upaya pencapaian tujuan pelajaran. Arends (2008) menyatakan suatu model pembelajaran mengacu pada pendekatan pembelajaran yang akan diterapkan. Selain itu, juga mengacu pada lingkungan pembelajaran dan manajemen kelas. Selanjutnya Arends mengemukakan ada empat ciri khas model pembelajaran, yaitu (1) rasional teoretis yang bersifat logis yang bersumber dari perancangannya, (2) dasar pemikiran tentang tugas pembelajaran yang hendak dicapai dan bagaimana siswa belajar untuk mencapai tujuan tersebut, (3) Aktivitas mengajar guru yang diperlukan agar model pembelajaran dapat dilaksanakan secara efektif, dan (4) lingkungan belajar yang diperlukan untuk mencapai tujuan.

Joyce \& Weil (1999) mengemukakan lima unsur penting sebagai uraian dari suatu model pembelajaran, yaitu (1) sintak, yakni suatu urutan kegiatan yang biasa juga disebut fase, (2) sistem sosial, yakni peranan guru dan siswa serta jenis aturan yang diperlukan dalam pembelajaran, (3) prinsip reaksi, yakni memberi gambaran kepada guru tentang cara memandang atau merespon pertanyaan siswa, (4) sistem pendukung, yakni kondisi yang diperlukan oleh model, dan (5) dampak instruksional dan pengiring.

\section{METODE PENELITIAN}

Jenis penelitian ini adalah penelitian pengembangan (research and development). Pengembangan model P2SK mengikuti fase-fase pengembangan oleh Plomp (1999), yaitu (a) fase investigasi awal (preliminary investigation), (b) fase perancangan (design), (c) fase realisasi (realization/construction), (d) fase pengujian, evaluasi, dan revisi (test, evaluation and revision), dan (e) implementasi (implementation), yang telah dimodifikasi dengan memasukkan komponen-komponen model pembelajaran yang dikemukakan Joice dan Weil (2009), yaitu: (a) sintaks, (b) sistem sosial, (c) prinsip reaksi, (d) sistem pendukung, dan (e) dampak instruksional dan pengiring, serta kriteria kualitas model pembelajaran mengacu pada Nieveen (2013) yaitu valid, praktis, dan efektif.

Uji coba dilaksanakan di kota Parepare, dengan memilih beberapa sekolah sebagai tempat melakukan uji coba. Pengamatan aktifitas siswa dilakukan oleh satu pengamat, siswa yang dipilih untuk diamati aktivitasnya yang dipandang mewakili seluruh karakteristik siswa. Beberapa pertimbangan yang dilakukan pada saat uji coba, diantaranya: (1) pelaksanaan uji coba lebih dari satu kali, (2) aktifitas siswa yang diamati dilakukan secara berkelompok yang dipandang mewakili dari seluruh siswa. Untuk melihat derajat keefektifan dan kepraktisan P2SK, maka akan dilakukan langkah-langkah berikut ini: (1) Mencermati dan mengkaji kembali teori-teori pendukung model menjadi lebih tepat 
dan fokus, (2) Meminimalkan semua keterbatasan-keterbatasan dan kelemahan-kelemahan yang terjadi pada saat uji coba di tahun kedua, (3) Melakukan uji coba (uji coba pada tahun kedua) dan kegiatan diseminasi.

\section{HASIL DAN PEMBAHASAN}

Model pengajaran dan pelatihan strategi kognitif disingkat model P2SK yang mengembangkan berpikir kritis. Model P2SK yang dikembangkan merupakan petunjuk bagi guru atau pendidik yang memadukan pengajaran dan pelatihan strategi kognitif denggan berpikir matematika dalam mengembangkan kemampuan berpikir kritis. Anderson \& Krathwohl (2001) yang menyatakan bahwa mengajarkan dan melatih kemampuan siswa tentang cara atau strategi kognitif, sangat berpotensi dapat mengatur dan mengontrol proses berpikir yang dilakukan.

Adapun sintak model P2SK, dikembangkan dari tahap-tahap berpikir menurut Shafer \& Foster (1997) meliputi 3 tahap, yaitu; refroduction, connection, dan reflection. Lebih jelasnya dapat dilihat pada tabel berikut ini.

Tabel 1. Tahap-tahap berpikir kritis dan kreatif oleh Shafer \& Foster (1997)

\begin{tabular}{lcc}
\hline \multicolumn{2}{c}{ Tahap } & Kegiatan siswa \\
\hline $\begin{array}{l}\text { 1. } \\
\text { (refroduction) }\end{array}$ & Merefresentasikan kemampuan dalam mengenal atau mengetahui fakta dasar, \\
2. & menggunakan algoritma, dan menggeneralisasikan keterampikan tekhnis. \\
Koneksi & Mendemonstrasikan kemampuan dalam mengintegrasi informasi, membuat \\
& keterkaitan antara konsep-konsep matematika, memilih rumus/strategi yang \\
3. & tepat digunkan dalam menyelesaikan masalah, mencari solusi non rutin. \\
(reflection) & Melakukan komunikasi matematis, menganalisis algoritma, melakukan \\
& interpretasi, menyampiakan argument atau bernalar secara logis, menekukan \\
& pola umum, konjektur serta membuat generalisasi secara formal.
\end{tabular}

Paparan dari jenis pembelajaran diatas, tentu bukan cara pengajaran yang baik dalam menyampaikan informasi kepada siswa tahap demi tahap. Oleh karena itu, pengajaran yang baik adalah mengajarkan siswa bagaimana belajar, bagaimana mengingat, bagaimana berpikir, dan bagaimana memotivasi diri mereka sendiri (Ennis; 2008 dan Fisher; 2001). Dengan demikian pengajaran dan pelatihan tentang cara memahami tugastugas, dan menguasai materi pelajaran, serta memasukkan ke dalam ingatan dapat dilakukan cara mengulang bahan tersebut merupakan strategi kognitif yang dibutuhkan saat ini.

Bacraharya (2010), dan Anderson \& Krathwohl (2001) menyatakan bahwa ketika siswa melakukan eksplorasi terhadap pemacahan masalah, beragam strategi yang 
kemungkinan dapat dilakukan. Misalnya penggunaan heuristik (heuristic), siswa tidak bekerja secara membabi buta, tetapi dengan penggunaan gambar. Strategi lain menurut Anderson \& Krathwohl adalah berpikir deduktif dan berpikir induktif. Sedangkan menurut Winkel (1996) menyebutkan strategi kognitif memecahkan dalam masalah adalah prosedur berpikir mundur atau prosedur berpikir maju. Berpikir mundur yaitu bertitik tolak dari tujuan yang telah diketahui dan menemukan jalan untuk menuju ke sana. Sedangkan berpikir maju yaitu berangkat dari garis star, kemudian memikirkan berbagai jalan untuk sampai pada tujuan, bahkan dengan jalan mencobanya. Untuk itu, guru dapat mengorganisasi siswa dalam belajar dengan strategi kognitif, sehingga siswa dengan mudah mengidentifikasi dan menjustifikasi suatu konsep, menggeneralisasi, menganalisis suatu algoritma, dan memecahkan masalah.

Arends (2008) dan Paul \& Elder (2005) menyatakan bahwa menyajikan dan mengevaluasi hasil kerja siswa dengan berbagai artifak merupakan kulminasi dari pembelajaran. Melalui interaksi seperti diskusi, siswa mampu menjelaskan konsep, teori, gagasan dan pikirannya dalam suatu kelompok, menyelesaikan suatu pekerjaan. Analisis algoritma dan pemecahkan masalah, dapat dilakukan oleh siswa seperti; memeriksa, memperbaiki, dan memberikan penjelasan terhadap pemecahan masalah dengan lengkap, benar, dan beralasan.

Paparan diatas menunjukkan bahwa model P2SK yang didesain atau dirancang merupakan perpaduan pengajaran dan pelatihan strategi kognitif dengan berpikir dalam mengembangkan kemampuan berpikir kritis. Adapun komponen-komponen model P2SK mengacu pada pendapat Joyce \& Weil (2009) menyatakan bahwa suatu model pembelajaran mencakup lima komponen, yaitu; sintak, sistem sosial, prinsip reaksi, sistem pendukung, dan dampak instruksional dan dampak pengiring. Penjelasan dari masingmasing komponen adalah sebagai berikut.

\section{Sintak}

Sintaks model P2SK yang telah dirancang terdiri dari 5 fase, yaitu fase I penyampaian tujuan pembelajaran; fase II mendemonstrasikan strategi kognitif dalam belajar; fase III penerapan strategi kognitif dalam memecahkan masalah; fase IV menggenarlisasi dan menganalisis algoritma; dan fase $\mathrm{V}$ kesimpulan. Berikut ini merupakan gambaran umum tentang sintak model P2SK. 


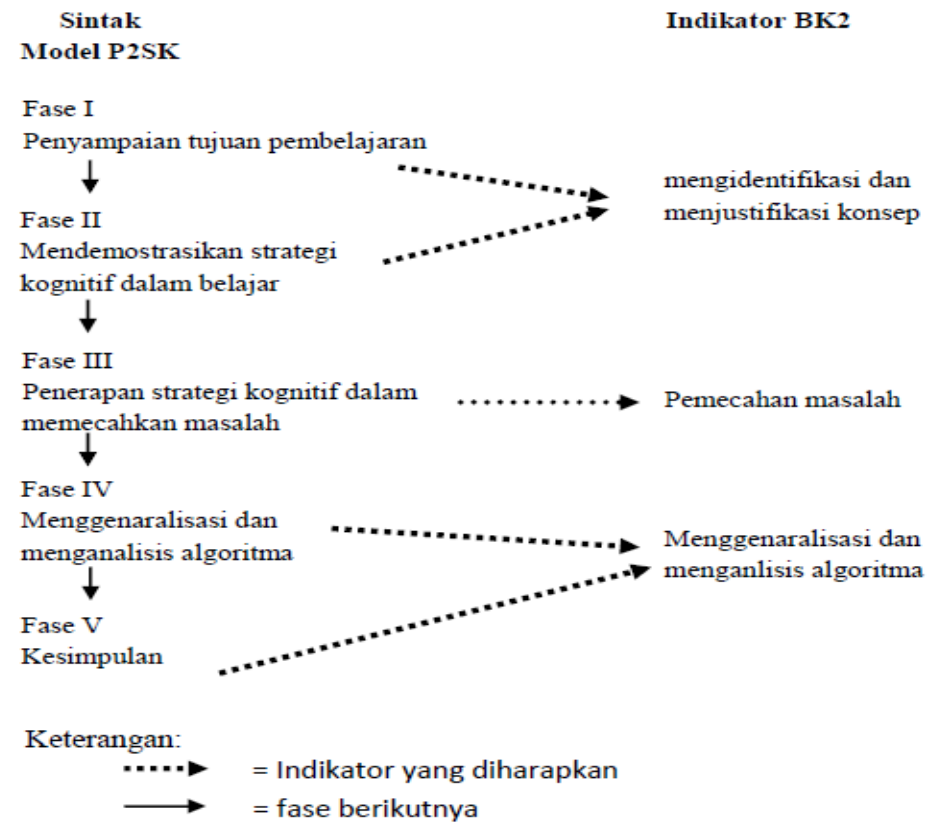

Gambar 1. Sintak model P2SK

\section{Sistem Sosial}

Mengacu pada uraian tentang sistem sosial model pembeajaran, maka sistem sosial model yang dikembangkan ini adalah menganut pola hubungan yang berimbang antara guru dan siswa. Pada fase-II mendemosntrasikan strategi kognitif dalam belajar. Pada fase ini, siswa mengidentifikasi dan menjustifikasi konsep-konsep dasar matematika, dengan cara membuat catatan pinggir, atau dengan menggraisbawahi isi bacaan sebagai upaya memahami materi ajar.

Fase III penerapan strategi kognitif dalam memecahkan masalah. Pada fase ini siswa banyak melakukan proses matematisasi dan merencanakan strategi dalam kaitannya dengan koneksi antara suatu konsep dengan konsep lain. Beberapa proses matematisasi yang dilakukan yaitu mengubah (transform) permasalahan dari dunia nyata ke bentuk matematika atau justru sebaliknya yaitu menafsirkan suatu hasil atau model matematika ke dalam permasalahan aslinya, sedangkan merencanakan strategi yaitu memilih dan menggunakan strategi kognitif untuk memecahkan masalah.

Fase IV menggenaralisasi dan menganalisis algoritma. Pada fase ini siswa melakukan komunikasi, penalaran, dan argumentasi dalam kaitannya merefleksikan proses dan hasil pemecahan masalah. Komunikasi berupa sajian kepada orang lain disertai penjelasan serta justifikasi. Sedangkan penalaran dan argumetasi meliputi kemampuan menalar dan memberi alasan. Kemampuan ini berakar pada kemampuan berpikir secara logis untuk melakukan analisis terhadap informasi untuk menuju kesimpulan. 
Fase V kesimpulan, yaitu jawaban akhir yang berikan oleh siswa setelah melakukan proses mengidentifikasi dan menjustifikasi konsep, penerapan strategi kognitif dalam pemecahan masalah, pengembangan (menggenaralisasi) dan analisis algoritma atau prosedur pemecahan masalah. Bentuk kesimpulan yang diharapkan meliputi ringkasan terhadap matemari yang telah dipelajari yang dapat diterima dan diyakini kebenarannya.

\section{Prinsip Reaksi}

Berdasarkan pengertian umum prinsip reaksi, maka peranan guru dalam model pembelajaran untuk mengembangkan kemampuan berpikir kritis ini menjadi cukup dominan, antara lain: (1) menyediakan sumber-sumber belajar, (2) menyampaikan informasi tentang tugas dan materi matematika, dan (3) mengajarkan dan melatih siswa strategi kognitif.

Mengacu kepada peranan guru secara umum sebagaimana dikemukakan di atas, maka beberapa perilaku guru yang diharapkan dalam model pembelajaran ini adalah sebagai berikut:

a. Menciptakan suasana yang kondusif pembelajaran dan membantu siswa menyiapkan segala sesuatunya sebelum mengikuti pelajaran. Misalnya, menyampaian kompetensi dasar, indikator, dan tujuan, baik yang berkaitan dengan materi matematika maupun yang berkaitan dengan strategi.

b. Memberikan kesempatan kepada siswa melakukan eksplorasi dan transformasi pengetahuan antara siswa dengan siswa, atau memberikan kesempatan kepada siswa melakukan prediksi dan hipotesis, mencoba solusi lain dan mendiskusikannya.

c. Menyampaikan informasi tentang konsep matematika dan strategi kognitif secara terpadu. Misalnya, sambil menyampaikan masalah matematika tertentu, guru mengajak siswa untuk membuat catatan pinggir dan menggarisbawahi hal-hal penting yang terdapat dalam bahan ajar.

d. Mengarahkan siswa menjawab pertanyaan atau tugas yang terdapat pada lembar kegiatan, dengan menyampaikan langkah penyelesaian, memonitorin, dan memeriksa kembali selesaian.

e. Memberikan kesempatan kepada siswa untuk menyajikan temuan-temuan mereka didepan kelas, hal ini memunkinkan terdapat perbedaan solusi atas penyelesaian yang diperoleh dari tiap-tiap kelompok.

f. Membimbing siswa menerapkan strategi kognitif. Misalnya, melatih siswa membuat catatan pinggir, menggarisbawahi, atau menuntun siswa menggunakan heuristik, 
mengikuti prosedur berpikir maju, prosedur berpikir mundur, prosedur berpikir deduktif, atau prosedur berpikir induktif dalam menyelesaikan masalah.

g. Menghargai segala aktivitas siswa yang mendukung proses pembelajaran (penguatan positif) dan mengarahkan aktivitas siswa yang menghambat proses pembelajaran (penguatan negatif).

\section{Sistem Pendukung}

Sistem pendukung suatu model pembelajaran adalah hal-hal yang dapat mendukung tercapainya tujuan pembelajaran dengan menerapkan model itu (Sherlyn \& Bessick, 2008). Hal-hal yang diamaksud berupa perangkat, dan alat/bahan. Untuk model P2SK ini dibutuhkan sistem pendukung, seperti: Rencana pembelajaran (RP), Bahan Ajar (BA), dan lembar Kerja Siswa (LKS).

\section{Dampak Instruksional dan Dampak Pengiring}

Ditegaskan oleh Joyce \& Weil (1999), dan Glaser (2001) menyatakan bahwa penerapan suatu model pembelajaran diarahkan untuk menopang pencapaian secara optimal sasaran atau tujuan pembelajaran yang telah ditetapkan. Bahkan pada perinsipnya pengguna model harus berupaya mensinergikan semua komponen model itu dalam rangka mencapai tujuan pembelajaran. Tujuan pembelajaran terbagi atas tujuan utama yang bersifat segera/mendesak untuk dicapai (instructional effect) dan tujuan pengikut/pengiring yaitu tujuan yang tidak segera dapat dicapai atau hasilnya tidak segera dapat dipetik setelah pembelajaran berlangsung, tetapi diharapkan dalam waktu yang relatif lama (nurturant effect).

Pada kajian sebelumnya telah dijelaskan bahwa indikator kemampuan berpikir kritis pada fase mengidentifikasi dan menjustifikasi konsep adalah siswa memilih atau menetapkan konsep-konsep yang utama, kemudian memberikan penjelasan dengan katakatanya sendiri yang lengkap, dan bernilai benar. Pencapaian indikator ini ditempuh melalui aktifitas membaca dan memahami uraian kegiatan yang terdapat pada BA, selanjutnya menginterpretasi dan membuat asumsi, kemudian menjelaskan kepada kawankawanya.

Fase Penerapan strategi kognitif dalam memecahkan masalah. Pada fase penerapan strategi kognitif dalam memecahkan masalah, siswa mengidentifikasi soal (diketahui, ditanyakan, kecukupan unsur) dan membuat model dengan benar, kemudian penyelesaiannya dengan benar. Pada fase ini siswa untuk berpikir membuat solusi atau jawaban, dan membuat gagasan, menyampaikan pendapat atau ide. 
Fase Menganalisis Algoritma dan Menggeneralisasi. Pada fase menggeneralisasi dan menganalisisi algoritma ada 2 yaitu: (1) siswa mampu memeriksa, memperbaiki, dan memberikan penjelasan setiap langkah algoritma pemecahan masalah dengan lengkap dan benar, dan (2) siswa mampu melengkapi data pendukung, menentukan aturan umum, dan memberikan penjelasan tentang cara memperolehnya dengan lengkap dan benar. Beberapa manfaat menggeralisasi, antara lain: dapat meningkatkan penguasaan materi , siswa lebih cepat dan mudah memahami materi, menemukan keterkaitan antar konsep, dan mampu mengaplikasikan konsep yang telah dipahami pada bidang lain.

Hasil-hasil penelitian ini memperkaya temuan sebelumnya, diantaranya: Innabi (2003), Gokhale (2005), dan Dori \& Bechler (2005) menyatakan bahwa melengkapi datadata pendukung pada suatu jawaban dapat menambah wawasan dan penguasaan materi lebih baik. Respon siswa untuk memberikan penjelasan cara memperolehnya atas jawaban mereka, dapat mendorong minat belajar baik secara mandiri maupun kelompok.

\section{KESIMPULAN}

Berbagai upaya-upaya yang sistematis, terukur, dan berkelanjutan dalam pembelajaran, sehingga perlu dikembangkan model pengelolaan pembelajaran jangka panjang, dan pengembangan perangkat yang mendukung pelaksanaan model tersebut. Model pengajaran dan pelatihan strategi kognitif disingkat model P2SK yang mengembangkan kemmapuan berpikir kritis dan kreatif. Model ini dikembangkan secara rasional berdasarkan teori-teori pendukung, diantaranya teori-teori belajar, teori konstruktivis, dan kondisi pembelajaran saat ini. Model ini memiliki beberapa komponenkomponen, yaitu: 1. Sintaks; 2. Sistem sosial; 3. prinsip-prinsip reaksi; 4. sistem pendukung; dan 5. dampak instruksional dan pengiring. Model ini juga dilengkap dengan petunjuk pelaksanaan, meliputi: 1. tugas-tugas perencanaan; 2. tugas-tugas interaktif; 3. lingkungan belajar dan pengelolaan tugas; 4. evaluasi.

\section{REFERENSI}

Anderson \& Krathwohl. (2001). A Taxonomy for learning Teaching and Assessing. A Revision of Bloom Taxonomy of Educational Objectives. Rearson Educational

Arends, R. L. (2008). Learning to Teach (Edisi terjemahan). Yogyakarta: Pustaka Pelajar. Bacraharya, K. (2010). Teaching Mathematics Through ABC Model of Critical thinking. Mathematics Education Forum, 28(2), Year 14, 13-17. Thachal Kathmandu: Mahendra Ratan Campus.

Bell, T. (1981). Promting Thinking Through Physical Education, Learning and Teaching in Action, 1: 35-40. 
Dori, Y. J. \& Belcher, J. (2005). How does technology-enabled active learning affect tunder graduate students' understanding of electro magnetism concepts? The Journal of Learning Science and Mathematics, 14(2), 243-279. Lawrence Erlbaum Associates, Inc.

Ennis, R. H. (2008). Nationwide testing of critical thinking for higher education: Vigilance required. Teaching Philosophy 31(1), 1-26.

Fisher, A. (2001). Critical Thinking in Introduction. Australia: Cambridge University Press.

Glaser, E. (2001). An Experiment in the Development of Critical Thinking. Advanced School of Education at Teacher's College. Columbia University.

Gokhale, A. (2005). Collaborative Learning Enhances Critical Thinking. Journal of Technology Education, 7(1).

Innabi, H. (2003). Aspects of Critical thinking in Classroom Instruction of Secondary School Mathematics Teachers in Jordan. The Mathematics Education into the 21st Century Project. Proceeding of The International Conference. The Decidable and the Undecidable in Mathematics Education. Czech Republic: Brno.

Joyce \& Weil. (1999). Models of Teaching. $5^{\text {th }}$ Edition. USA: Allyn and Bacon.

Nieveen. N. (2013). Educational Design Research: Netherlands: Netherlands Institute for Curriculum Development.

Paul, R. \& Elder, L. (2005). Critical thinking and the art of substantive writing. (Part I). Journal of Developmental Education. 29(1). 40-41.

Shafer \& Foster. (1997). The Changin face of Assesment. Principled Practice, 1(2).

Sherlyn \& Bessick. (2008). Improved Critical Thinking Skills as a result og direct instruction and relationship to academic achievement. A Dissertation Submitted to the Graduate Studies and Research in Partial Fulfillment of the Requirements for the Degree Doctor of Education. Indiana University of Pennsylvania.

Winkel, W. S. (1996). Psikologi Pengajaran. Jakarta: Grasindo. 